\title{
Determinants of Service Innovation: a Typology of Sports Federations
}

\section{Mathieu Winand}

School of Sport, University of Stirling

FK9 4LA, Scotland, UK

E-mail: Mathieu.winand@stir.ac.uk

Fax number: + 44(0)1786 466477

\section{Steven Vos}

Policy in Sports \& Physical Activity Research Group, Department of Kinesiology, University of Leuven

Tervuursevest, 101, B-3001, Leuven, Belgium

and

School of Sport Studies, Fontys University of Applied Sciences

5644 HZ Eindhoven, The Netherlands

E-mail : steven.vos@faber.kuleuven.be

\section{Thierry Zintz}

Olympic Chair in Management of Sport Organizations,

Faculté des Sciences de la Motricité, Université catholique de Louvain

Place P. de Coubertin, 1 Bte L8.10.01 B-1348 Louvain-la-Neuve, Belgium

E-mail: thierry.zintz@uclouvain.be

Fax number: +32(0)10 473106

\section{Jeroen Scheerder}

Policy in Sports \& Physical Activity Research Group, Department of Kinesiology, University of Leuven

Tervuursevest, 101, B-3001, Leuven, Belgique

E-mail : jeroen.scheerder@faber.kuleuven.be

Fax number: +32(0)16 329196

\section{Biographical notes:}

Mathieu Winand is Lecturer in Sport Management in the School of Sport at the University of Stirling (Scotland, UK). He is also involved as associate researcher in the Olympic Chair Henri de Baillet Latour \& Jacques Rogge in Management of Sport Organisations from the Université catholique de Louvain in Belgium. Dr. Winand's expertise is in the area of innovation in sport organisations, organisational performance, sport governance and organisational change.

Steven Vos is with the Policy in Sports \& Physical Activity Research Group, Department of Kinesiology (University of Leuven, Belgium) and is Lecturer in Management in Sport \& Physical Activity at the School of Sport Studies, Fontys University of Applied Sciences (The 
Netherlands). His main areas of research are policy and management in sport and physical activity, supply and demand of grassroots sport and sport participation.

Thierry Zintz is Dean of the Faculté des Sciences de la Motricité at the Université catholique de Louvain (Belgium). He is Professor of Sport Management and Holder of the Olympic Chair Henri de Baillet Latour \& Jacques Rogge in Management of Sport Organisations at the Université catholique de Louvain. His research interests include configurational approaches, strategies and governance of sport organisations.

Jeroen Scheerder is an associate professor at the Department of Kinesiology, Faculty of Kinesiology and Rehabilitation Sciences, University of Leuven (Belgium). He is the head of the Policy in Sports and Physical Activity Research Group. His research and teaching focuses on consumption and participation patterns in leisure-time sports and public policy in sports and physical activity.

\begin{abstract}
The increasing commercialisation of the sports sector and changing consumer demands are some of the issues that create challenges for non-profit sports in contemporary society. It is important for managers and marketers of these organisations to innovate because innovation is a way to grow within a competitive environment and to meet customers' expectations. The present study aims to develop an explorative typology of sports federations based on their attitudes and perceptions of determinants of innovation and their innovation capacity. A cluster analysis suggested three clusters with different responses towards service innovation: traditional sports federations, financially secure sports federations and competitive sports federations. Sports federations perceiving competition in terms of financial and human resources, favouring change and paid staff involvement in decision-making processes, and with negative economic perceptions are significantly more innovative. These findings have implications for the management and marketing of non-profit sports organisations.
\end{abstract}

Keywords: service innovation, determinants of innovation, sports federations, non-profit sports organisations

\title{
Acknowledgments
}

The authors would like to thank Jos Feys for his valuable assistance in collecting the data and Professor David Lavallee and Professor Leigh Robinson for their assistance in writing this article. 


\section{Determinants of Service Innovation: a Typology of Sports Federations}

\section{Introduction}

Non-profit sports organisations (NPSOs), like sports federations, are being encouraged to adapt themselves to the expectations of their stakeholders and individual members' satisfaction and attraction of new members represent major goals. Given the growing number of commercial sports providers and the popularity of non-organised sports activities (Vos et al., 2012), it is crucial for sports federations to implement new services to retain and attract members. The adoption of new services to satisfy their members should be considered as innovations. However, only a few studies have attempted to develop a theory of innovation in the complex non-profit sector, which has a distinctive economic structure and its own rationality (Vos et al., 2012). Also in the non-profit sports sector, studies on innovation are rare (Hoeber and Hoeber, in press). In line with suggestions of Newell and Swan (1995), the context and issues faced by NPSOs argue in favour of a new understanding of the way innovation is understood and emerges through key determinants. NPSOs do not compete for profit. They compete for financial support, sports results, and membership participation (Newell and Swan, 1995). Sports federations innovate to attract and retain members (Newell and Swan, 1995; Thibault, Slack, and Hinings, 1993) and might develop an attitude favouring innovation to cope with their competitive environment. This type of sports federations would be more innovative. This is precisely where this paper wants to contribute, and its purpose is to understand the characteristics of sports federations in relation to innovation. Hence, the following research question is addressed: what type(s) of sports federations is (are) innovative?

The present study aims to highlight an explorative typology of sports federations based on their attitudes and perceptions of determinants of innovation. The relationship between the 
type of organisation and level of innovation is examined. The paper contributes to the body of research on service innovation in non-profit organisations and aims to stimulate thinking about sports federations such as innovative organisations.

First, the concept of innovation is presented with a focus on the process and determinants leading organisations to innovate. The concept of service innovation as opposed to product innovation is clarified in order to illustrate what innovations sports federations might develop. Potential determinants of innovation in sports federations are described. Second, the methods to assess sports federations' attitudes and perceptions on these determinants and to evaluate their degree of innovations are put forward. Third, the typology of sports federations with regard to their attitudes and perceptions of determinants of innovation is shown. The relationship between the number of innovations implemented by sports federations and their type is also considered. Finally, the results and implications for the management and marketing of non-profit sports organisations are discussed.

\section{Theoretical background}

\section{Innovation and determinants of innovation}

The present paper fits with the stream of research on organisational innovativeness (Wolfe, 1994) which aims to identify determinants that stimulate innovation in organisations. The unit of analysis is thus the organisation (Wolfe, 1994). At the organisational level, innovation has been defined as the adoption of an idea or behaviour new for the organisation (Damanpour, 1996; Damanpour and Schneider, 2006; Zaltman, Duncan, and Holbek, 1973). This broad definition contrasts with the narrow definition of economists (Damanpour and Aravind, 2012; Roberts, 1988) who consider something as new when it refers to a whole sector (or even to the world). However, we argue that from an organisational perspective, changes that new practices have generated within organisations are relevant, as well as what elements have led to the adoption of new practices. Innovation is considered a subset of 
organisational change (Damanpour and Aravind, 2012). It leads organisations to transfer from current to future practices (Nadler and Tushman, 1997).

Organisations are innovative when they implement a new product/service for the first time to satisfy their users/customers/members. Furthermore, this innovation needs to be sustained over time to be considered a success (Greenhalgh et al., 2004). Throughout its implementation, innovation is influenced by multiple and different determinants (Mohr, 1969). Internal factors such as the managerial willingness to innovate may be decisive to initiate the discussion about innovation. Furthermore, organisational and environmental factors are also relevant. In the literature, three main determinants of innovation are put forward, namely managerial, organisational and environmental levels (Damanpour and Schneider, 2006, 2008; Frambach and Schillewaert, 2002; Hoeber and Hoeber, in press). The managerial level refers to individuals in the organisation, their relationships with each other, their involvement in the decision making processes, and their leadership. From the managerial point of view, attitude of decision makers towards change and newness is considered crucial (Damanpour and Aravind, 2011; Frambach and Schillewaert, 2002). Contrasting with the creation of a favourable climate towards change (Damanpour and Schneider, 2006), static and traditional attitudes are obstacles to innovation (Mohr, 1969). Managers' attitudes towards innovation (e.g., risk-averse, tradition/contemporary, favouring change) might be a key determinant regarding the development of innovations. The organisational level refers to organisations' characteristics. Size and level of funding are crucial elements in the process of innovation (Damanpour and Schneider, 2006; Frambach and Schillewaert, 2002). However, their effect on innovation is arguable. On the one hand, larger organisations might have greater innovative needs but are able to attract more financial resources and skilled professionals to facilitate the process of innovation (Damanpour and Schneider, 2006; Frambach and Schillewaert, 2002). On the other hand, smaller organisations are more 
flexible, less bureaucratic and might easily and quickly adapt and accept change (Damanpour and Schneider, 2006). Financially secure organisations might better absorb the costs of an innovation and afford to take (more) risks (Damanpour and Schneider, 2006). The environmental level refers to the sector with which organisations operate (Damanpour and Schneider, 2006), including external and competitive pressures they face from their stakeholders. In highly competitive markets, organisations innovate to maintain their market position (Frambach and Schillewaert, 2002).

It is assumed that the way organisations perceive and develop attitudes towards these three determinants is linked with their propensity to innovate. The present paper focuses on innovation within sports federations. The core activity, context and issues faced by these sports organisations require a new understanding of the concept of innovation (Newell and Swan, 1995) with implications to (sports) services organisations in the non-profit sector.

\section{Sports federations' service innovation}

Sports federations do not typically provide tangible products but have, as strategic objectives, the requirement to organise sports activities and competitions for their members (i.e., individual members within non-profit sports clubs). They are service providers in the non-profit sports sector. The development of sports, under the supervision of sports federations, also goes through the diffusion of innovations, new practices and/or new rules (Newell and Swan, 1995).

According to Damanpour and Aravind (2012) and Hipp and Grupp (2005), the implementation of service innovations should be seen apart from product innovations. Even though the drivers for both product and service innovations are customers' demands for new services (Toivonen and Tuominen, 2006) and managerial decisions to provide new services to retain customers or attract new ones (Damanpour and Aravind, 2012; Miles, 2005), differences exist between them (Toivonen and Tuominen, 2006). Service innovation could 
result without any planning when emerging from a customer's need (Toivonen and Tuominen, 2006). Also, in contrast to products, services are acts or processes (Hipp and Grupp, 2005). When customers purchase a service, they do not receive ownership, but rather access to the service for a defined period of time (Lovelock and Gummesson, 2004). Sportsmen/women receive access to sport facilities and equipment, or gain the right to use a sport trainer's expertise. Services cannot be stored and are characterised by customer integration where production and consumption are simultaneous (Gallouj and Weinstein, 1997; Hipp and Grupp, 2005). At the same time, the intangible characteristic of services makes it more difficult to detect a modification or an improvement. However, although services are intangible before their use, they could have mental and physical tangible effects (e.g., sport training impact on the user's body and well-being) (Lovelock and Gummesson, 2004). The differences between services and products substantiates the need for a distinct theory on service innovation (Toivonen and Tuominen, 2006).

All services delivered by sports federations are not only sport oriented, but have a direct (or indirect) connection to their non-profit sport objectives (e.g., inform and assist individual sports members and affiliated non-profit sports clubs, manage sports competition calendars). Studying service innovation in sports federations contributes to the knowledge of service innovation in the non-profit sector. These sports service organisations could implement initiatives or services which are considered to be innovative if they are introduced for the first time in order to increase the satisfaction of their members, effectiveness of the organisation and/or service quality to their members (Lee, Ginn, and Naylor, 2009; Walker, 2008). The organisation of beach volley competitions is an example of sport service innovation adopted by volleyball federations and clubs. This new way of playing volleyball involves new services for referees, coaches, athletes and affiliated members (e.g., sports training programmes, access to adapted sports facilities). 
Organisational characteristics (i.e., in terms of size, membership, media coverage, level of funding) have, according to Newell and Swan (1995), a strong influence on the capacity of sports federations to innovate. Large sports federations, run by professional staff, attract substantial financial resources from membership, sponsorship and/or media coverage (Newell and Swan, 1995). In line with Damanpour and Schneider (2006), these financially secure organisations might be inclined to invest in risky innovations. In contrast, small sports federations essentially rely on volunteers. They attract little resources, mostly membership fees and sports administration/council grants (Newell and Swan, 1995). However, their organisational structure is simple and flexible (Hoeber and Hoeber, in press) so that they might easily adapt and accept changes.

Sports federations are open systems strongly influenced by their sports network (e.g., international and continental sports organisations) and stakeholders in their willingness and capacity to innovate (Newell and Swan, 1995). Thibault, Slack, and Hinings (1993) suggested that sports federations innovate in response to the competitive position of their sport in order to increase their program attractiveness to (new) members. Competitive and environmental pressures perceived by sports federations might stimulate change (Caza, 2000). Sports federations compete at national and international levels for financial support, sports results, and membership participation (Newell and Swan, 1995). They need to acquire (new) resources to survive and promote their sport. At national (and regional) levels, attraction of members and financial resources (grants and sponsorship) is a strategic imperative. In addition, the importance of different funding streams has an impact on sports federations. For instance, sponsorship revenues are associated with increasing demands for change to better serve the sponsors' interest (Newell and Swan, 1995). Funders' influence and the competition to obtain funds, whether public (i.e., grants) or private (i.e., membership fees, sponsorship), might have a considerable influence on innovation. At the international level, achieving 
relevant sports results during high level competitions (e.g., Olympic Games, World Championships and Grand Slams) are objectives for the reputation and image of both sports federations and their country. Sports federations and nations need to develop innovative strategies to hold competitive advantages in their increasingly competitive environment (De Bosscher et al., 2006).

However, despite competitive pressure, not all sports federations favour change and innovation. The importance of tradition in sports and resistance from multiple constituents who want to maintain the status quo, might serve as a deterrent or barrier to innovation (Newell and Swan, 1995; Wolfe, Wright, and Smart, 2006). Taylor (2004) identified two types of NPSOs that lie at opposite sides of a continuum, i.e., traditional/informal versus contemporary/formal. Their responses to innovation might be different. The managerial attitude towards newness developed within sports federations might affect how innovation and change are perceived. Managerial awareness of the necessity to develop new practices (e.g., new services, new sports activities) might be crucial for sports federations to innovate (Newell and Swan, 1995).

Furthermore, a large part of the success of innovations is due to professional management alongside innovation implementation (Caza, 2000). Committed staff and managerial support favour innovation in NPSOs (Hoeber and Hoeber, in press). Volunteer board members' crucial role in the governance and management of sports federations might have an influence on the successful implementation of innovations.

This paper aims to highlight groups of sports federations with different attitudes and perceptions towards determinants of innovation, and considers how these are linked with how much they innovate. Managerial attitude favouring change and commitment, as opposed to traditional and static attitudes, is a key determinant at the managerial level. Sports federations' financial capacity to invest in new services might also be critical. Economic health is a crucial 
determinant at the organisational level. Sports federations' size and structure are also central elements, but controversial with regards to their relationship to innovation. The competitive environment surrounding sports federations at the national/regional and international levels impacts on innovation. Competition for resources (i.e., financial and human resources) at the national and regional levels and international sport competitive pressure are also critical determinants at the environmental level.

In line with Newell and Swan (1995), the specific context and issues of sports federations argue in favour of a specific instrument assessing innovation and determinants of innovation in sports federations. However, to date no validated instrument has been developed to assess them in the context of NPSOs. This research aims to address this gap.

\section{Methods}

\section{Research context}

In the present paper, the focus is on regional sports federations in Belgium, recognised by the public authorities (i.e., Flemish and Walloon regions). As sport is organised and coordinated by the regions, most of the Belgian sports federations have had to split into regional sports federations to obtain grants from their governments (Scheerder, Zintz, and Delheye, 2011). As a consequence, regional sports federations in Belgium are in charge of the tasks and activities that are normally associated with national sports federations in other countries. There are 144 regional sports federations.

$$
\text { Insert Table } 1 \text { about here }
$$

Data

An online survey was developed in 2010 and sent to all of the 144 regional sports federations in order to assess attitudes and perceptions of managerial, organisational and environmental levels and the number of new initiatives (i.e., service innovations) they implemented (for full description of the method, see Winand, Scheerder, Vos, and Zintz, 
2011). Key individuals (e.g., the chair, the general secretary) were invited to complete the questionnaire, in line with the research method of Subramanian and Nilakanta (1996) on banking services innovation. Respondents were asked to rate 28 items (i.e., statements) on a Likert scale $(1=$ completely disagree to $5=$ completely agree $)$ intended to assess the attitudes and perceptions of the three-level determinants of innovations in sports federations (Table 1).

Respondents were also asked to indicate initiatives their sports federation had implemented before and after 2006, according to a list of general categories. These categories referred to services sports federations can offer (e.g., organisation of new sports disciplines, adaptation of sports activities for young or elderly members, new web site, new elite sports training system), in line with Subramanian and Nilakanta (1996) who used a list of services adopted by banks. Respondents described these initiatives and provided information about sustainability over time. The year 2006 was chosen to differentiate new (i.e., after 2006) and past (i.e., before 2006) initiatives. It represents a four-year time period before the survey during which initiatives are still considered to be new and not yet a routine, in line with the sports federations' quadrennial strategic plans. In total 101 sports federations participated in the survey, which equals a response rate of 70 percent.

\section{Variables}

Table 1 shows the three-level determinants of innovation, their description (i.e., expressed in categories and sub-categories) and their operationalisation with the 28 items. The items were adapted to the specific context of regional sports federations in Belgium. At the managerial level, the attitude of sports federation managers towards traditional management (i.e., bureaucracy, inflexible structure, against change, risk averse), as opposed to contemporary management, was assessed. In parallel, managerial attitude favouring change and newness (i.e., investment in new services, risk taking, openness to change, openness to members', sports clubs' and staff suggestions and expectations) was also considered, as well 
as attitudes towards contemporary management (i.e., professional management, involvement in decision making processes, staff corporate spirit) (Caza, 2000; Damanpour and Schneider, 2006; Frambach and Schillewaert, 2002; Hoeber and Hoeber, in press; Mohr, 1969; Taylor, 2004). At the organisational level, the perception of financial capacity (i.e., financial balance, risky financial investment, attraction of financial resources, economic health) was evaluated (Damanpour and Schneider, 2006). Size was also considered (Damanpour and Schneider, 2006; Frambach and Schillewaert, 2002; Hoeber and Hoeber, in press), and was measured through the number of affiliated members (Madella, Bayle, and Tome, 2005). Size categories were defined following both Flemish and Walloon regional sports systems (i.e., small, medium and large size). At the environmental level, the competition between sports federations at regional (i.e., attraction of members and grants, competition with commercial sports providers), at national (i.e., sport rivalry between regional sports federations) and at international levels (i.e., high level sport competition) was analysed (Caza, 2000; Frambach and Schillewaert, 2002; Newell and Swan, 1995; Thibault, Slack, and Hinings, 1993).

The total number of new initiatives developed by each sports federation was computed with a differentiation between sports and non-sports initiatives, after they were first filtered using their descriptions. Innovative sports federations were considered to be those which have implemented new or renewed sports and/or non-sports initiatives, activities or services for the first time during the last four years and have developed them continually. Therefore, in line with Gopalakrishnan and Damanpour (2000) and Jaskyte and Dressler (2005) who considered the number of innovations as a criterion for innovative organisations, the more new initiatives that were implemented, the more innovative a sports federation was considered to be.

\section{Analysis}

The statistical analysis consisted of three steps. First, Principal Component Analysis (PCA) was employed to construct scales of determinants of innovation, validated by 
Cronbach's alpha. Attitude or perception score (range from 1 to 5) for each scale for each sports federation was computed through an average of consistent items scores. Second, a cluster analysis (K-means) was applied to the scale scores to create a typology of sports federations. Third, the average number of new initiatives of each cluster (i.e., type) of sports federations was computed with a distinction between general and sports-specific services initiatives. The comparison of the average number of new initiatives between clusters of sports federations (ANOVA with Tukey's post-hoc test) significantly showed what type(s) of sports federation(s) is (are) more (or less) innovative, if any.

The relationship between size and innovation was analysed with a comparison of the average number of service innovations implemented between different size categories of sports federations (ANOVA with Tukey's post-hoc test). No significant result was highlighted between size and innovation in sports federations.

\section{Results}

Typology of sports federations

Exploratory PCA with varimax rotation was carried out on the attitudes and perceptions of the determinants of innovation of regional sports federations in Belgium. Factor analysis yielded five factors representing 17 items that explained 66.7 percent of the variance. Table 2 shows the five scales constructed, i.e., attitude regarding (1) staff involvement and (2) newness, perception of (3) regional competitive environment, (4) economic health and (5) national/international competitive environment. Eleven items of determinants of innovation did not meet a factor loading criterion and were therefore excluded for further analysis. Cronbach's alpha's ranged from .72 to .75 , and were considered to be satisfactory (Mueller, 1986; Nunnally, 1970).

Insert Table 2 about here 
Attitudes of decision-makers towards change and innovation (Factor 1, see Table 2) and involvement of professionals in decision-making processes (Factor 2, see Table 2) were identified as key determinants at the managerial level. Professionals, sports clubs and members can stimulate change in sports federations through their ideas and suggestions. Contemporary sports federations are highly open to expectations if volunteer board members favour change and newness. In contrast, this was found not to be the case, or only to a lesser extent, with traditionally managed sports federations.

Perceptions of international and national competitive environments (Factor 3, see Table 2) were considered separately from the perception of regional competitive environment (Factor 5, see Table 2). They were found to be key determinants at the environmental level. The (inter)national competitive environment represents the sports competition and rivalry between sports federations in and outside the country. The regional competitive environment consists of competition to attract financial resources (e.g., grants) and members.

The economic health of sports federations (Factor 4, see Table 2) was identified as a key determinant at the organisational level. Perceptions of financial balance, of good economic health and of financial investments are indicators of the financial capability of sports federations to survive and grow.

Insert Table 3 about here

The factors scores served as input for the cluster analysis. Three clusters were distinguished: (1) 'traditional' (23\%), (2) 'financially secure' (44\%), and (3) 'competitive' (33\%) sports federations. Table 3 shows the final cluster centres and average scale scores for all sports federations. In general, sports federations were found to favour positive attitudes regarding paid staff involvement $(M=4.08, S D=0.76)$, and newness $(M=3.81, S D=0.6)$. Perception of economic health $(M=2.93, S D=0.84)$, (inter)national $(M=3.0, S D=0.89)$, 
and regional $(M=3.54, S D=0.89)$ competitive environments is globally neutral, but varies among sports federations.

Sports federations in cluster 1 are named traditional sports federations in line with Newell and Swan (1995), Taylor (2004) and Wolfe, Wright, and Smart (2006). They perceive their environment as non-competitive and have lower attitude scores towards newness and staff involvement than other sports federations. Their perception of economic health is low.

Sport federations in cluster 2 show higher scores. They favour the development of new ideas and perceive good economic health and high (inter)national competitive environment in elite sport. They are named financially secure sports federations. In line with Damanpour and Schneider (2006) and Newell and Swan (1995), they attract sufficient financial resources which might allow them to better absorb the costs of innovations and to invest in innovations that might represent a risk. Sport federations in cluster 3 show very high scores for attitudes regarding staff involvement and perceptions of a regional competitive environment, but low scores for economic health perceptions. They are named competitive sports federations in reference to research (Caza, 2000; Newell and Swan, 1995; Thibault, Slack, and Hinings, 1993) which identified the competitive pressure non-profit organisations face to attract financial resources and members.

\section{Innovative type of sports federations}

Table 4 shows the total average number of general and sport service innovations implemented by regional sports federations in Belgium and the results of the ANOVA comparing the average number of service innovations for each cluster. The results showed that fifty-three percent of services provided by sports federations were new or renewed in the previous four years. They implemented an average of 4.5 general service innovations including 1.7 sport service innovations (37.8\%).

Insert Table 4 about here 
Competitive sports federations (cluster 3, see Tables 3 and 4) which develop highly positive attitudes involving staff in the decision making processes, high perceptions of regional competitive environment for the attraction of members and public resources and low perceptions of economic health, are significantly more innovative $(M=5.55, S D=3.8)$. Traditional sports federations (cluster 1 , see Tables 3 and 4) are significantly less innovative $(M=3.43, S D=2.54)$. They do not perceive competition for resources or sports results, despite a perception of limited financial capability. They are open for change and staff involvement which might lead them to develop some new or renewed activities. Financially secure sports federations (cluster 2, see Tables 3 and 4) are less innovative than competitive sports federations $(M=4.45, S D=3.1)$. They have high scores for attitudes and perceptions for each determinant of innovation. Furthermore, they perceive sufficient financial resources to invest in new services and a positive organisational atmosphere involving staff and favouring change and newness. Despite these high scores, their number of innovations does not significantly differ from traditional sports federations.

With regard to sport service innovations, there is a significant difference between traditional $(M=1.09, S D=0.85)$ and competitive $(M=2.7, S D=2.31)$ sports federations.

\section{Discussion and Conclusion}

We have presented a typology classifying three types of sports federations: 'traditional', 'financially secure' and 'competitive'. This typology is based on five underlying dimensions of attitudes and perceptions of determinants of innovation. Differences were found between types of sports federations on the average number of service innovations they have implemented. This supports Taylor's (2004) suggestion of types of sports federations for which the response to innovation differs. 
Traditional sports federations were found to be the less innovative. Nevertheless, they do develop some new initiatives. They are open to change and staff suggestions and involvement, but perceive low environmental pressure and weak financial resources.

Financially secure sports federations would logically have been considered as the most innovative, as they might better absorb innovation costs and be inclined to invest in risky innovations, but they are not. These sports federations might have lower incentives to innovate in comparison with competitive sports federations. In line with Hull and Lio (2006), these NPSOs may not see why it is essential for their organisation to continuously innovate because they have a solid financial balance and successfully deal with their stakeholders and environmental pressure. Another explanation might be that financially secure sports federations are more likely to adopt fewer, but more radical innovations generating more change.

Competitive sports federations perceive high pressure to attract human and financial resources. In line with Frambach and Schillewaert (2002), Newell and Swan (1995) and Thibault, Slack and Hinings (1993), the competitive environment these sports federations perceive might stimulate service innovation implementation. We assume a highly perceived regional competitive environment, together with high staff involvement and positive attitudes regarding change and newness favour service innovation in sports federations. Low perceptions of economic health might lead sports federations to find ways to solve poor financial results through innovation, if they are resource-competition oriented. Sports federations struggling to attract resources were found to be the most innovative. Therefore, we assume service innovation represents a way for sports federations to differentiate in order to develop resources to grow and survive.

No relationship between size and service innovation has been found in this research. In line with the literature (Damanpour and Schneider, 2006; Frambach and Schillewaert, 2002), 
this relationship is arguable and our results show that sports federations can innovate regardless of size. Indeed, results show that regional sports federations innovate on average once a year (four years investigated, $M=4.08, S D=0.76$ ). Nevertheless, because most regional sports federations in Belgium are small (68\% of them have less than 10,000 members) and have flexible and simple structures (Zintz and Camy, 2005), we might assume a relationship between service innovations and small size with a simple structure.

Further research should be conducted to analyse innovation in NPSOs and its impact on performance. Particularly, we call for more research on service innovation in these sports service organisations which have not yet been properly studied and of which a contribution to literature on (service) innovation and non-profit (sports) organisations is needed, as supported by Drejer (2004).

Limitations of this study are related to the specific sports federations analysed. Because the sports federations were small-sized organisations in Belgium, the findings of this study can not necessarily be applied to all types of sports federations. However, these organisations do share similar characteristics with most sports federations (Bayle and Robinson, 2007; Winand et al., 2010). Therefore, we were able to give an overview of how studies on innovation could be achieved in this context and what to learn from them. Another limitation relates to the number of persons surveyed as only one key person per sports federation filled out the questionnaire, following Subramanian and Nilakanta's (1996) research method. Nevertheless, our respondents have high level of strategic experience within their sports federation. Finally, innovativeness was based on the number of innovations implemented. We did not take into account the radicalness (magnitude of change the innovation produces; see Wolfe, 1994) of service innovations implemented by sports federations. The level of change generated by innovation in the organisation might be considered to assess innovativeness. Further studies should investigate the radicalness 
attribute (i.e., radical vs incremental) of service innovations and their impact on organisational change.

The motives for innovation in NPSOs are different from for-profit organisations. NPSOs innovate to get more people involved in their sporting activities and to improve the quality of their sports programs. The reason behind this might be to increase membership fees and financial support from public authorities and sponsors, and promote sports values and generate recognition. Furthermore, the mixed human resources in NPSOs (combining volunteers and paid staff) and mixed financial resources (combining public and private resources) might impact on innovation processes. Positive attitudes among volunteers and staff involvement are crucial for NPSOs to adapt and accept change. Financially secure NPSOs were not the most innovative. As profitability is not a goal for NPSOs, they do not all favour change. On the contrary, NPSOs for which resources are scarce, and which perceive a highly regional competitive environment, were the most innovative.

Sport policy implications can be highlighted from this research. The financial support sports administrations and governments assign to sports federations is crucial for them to develop sports activities, including elite sport. However, in line with Newell and Swan (1995), we showed that sports federations competing for resources are more innovative. Indeed, they are forced to find new ways to collect resources within their competitive environment. Consequently, they aim to attract resources from sponsors and membership fees. These revenues are associated with increasing demands for change to better serve the interests of the members and sponsors. Sports administrations and governments should stimulate change and innovations in sports federations and give them the will to develop and implement new ideas and new services. Reward systems for service innovation might be a solution, as well as incentives to develop new funding streams. 
Our research suggests that it is better for innovativeness when people in the organisation are highly involved and favour change and newness, and perceive low level of resources (i.e., financial and membership) and high competitive pressure to attract them. Managers of sports federations willing to innovate may favour a positive climate between volunteers and paid staff, involving the latter in the decision-making processes, and supporting their creativity and enthusiasm in developing new ideas. They should make staff realise that their organisation's regional environment is competitive in terms of resources attraction (i.e., members, private and public resources) and that it is necessary they develop new activities.

The non-profit sports sector is a competitive market. NPSOs compete for financial support, sports results, and membership participation (Newell and Swan, 1995). In line with Frambach and Schillewaert (2002), this research supports the idea that NPSOs innovate to maintain their sports sector position. They implement service innovations to retain their affiliated members/users and to attract new ones (future and former users of their services) who purchase, or might be interested in purchasing, services provided by competitors. Innovation is here seen as a marketing tool for generating member oriented services.

\section{References}

Bayle, E. and Robinson, L. (2007) 'A framework for understanding the performance of national governing bodies of sport', European Sport Management Quarterly, Vol. 7, No. 3, pp.249-268.

Caza, A. (2000) 'Context receptivity: Innovation in an amateur sport organization', Journal of Sport Management, Vol. 14, No. 3, pp.227-242. 
Damanpour, F. (1996) 'Bureaucracy and innovation revisited: Effects of contingency factors, industrial sectors, and innovation characteristics', Journal of High Technology Innovation Management, Vol. 7, No. 2, pp.149-173.

Damanpour, F. and Aravind, D. (2011) 'Managerial Innovation: Conceptions, Processes, and Antecedents', Management and Organization Review. DOI: 10.1111/j.17408784.2011.00233.x

Damanpour, F. and Aravind, D. (2012) 'Organizational structure and innovation revisited: From organic to ambidextrous structure' in Mumford M. (Ed.), Handbook of Organizational Creativity, Elsevier, London, pp.479-509.

Damanpour, F. and Schneider, M. (2006) 'Phases of the adoption of innovation in organizations: Effects of environment, organization, and top managers', British Journal of Management, Vol. 17, No. 2, pp.215-236.

Damanpour, F. and Schneider, M. (2008) 'Characteristics of innovation and innovation adoption in public organizations: Assessing the role of managers', Journal of Public Administration Research and Theory, Vol. 19, No. 3, pp.495-522.

De Bosscher, V., De Knop, P., Van Bottenburg, M. and Shibli, S. (2006) ‘A Conceptual Framework for Analysing Sports Policy Factors Leading to International Sporting Success', European Sport Management Quarterly, Vol. 6, No. 2, pp.185-215.

Drejer, I. (2004) 'Identifying innovation in surveys of services: a Schumpeterian perspective', Research Policy, Vol. 33, No. 3, pp.551-562.

Frambach, R.T. and Schillewaer, N. (2002) 'Organizational innovation adoption. A multilevel framework of determinants and opportunities for future research', Journal of Business Research, Vol. 55, No. 2, pp.163-176.

Gallouj, F. and Weinstein, O. (1997) 'Innovation in services', Research Policy, Vol. 26, Nos. 4/5, pp.537-556. 
Gopalakrishnan, S. and Damanpour, F. (2000) 'The impact of organizational context on innovation adoption in commercial banks', IEEE Transactions on Engineering Management, Vol.47, No. 1, pp.1-13.

Greenhalgh, T., Robert, G., MacFarlane, F., Bate, P. and Kyriakidou, O. (2004) 'Diffusion of innovations in service organizations: Systematic review and recommendations', The Milbank Quarterly, Vol. 82, No. 4, pp.581-629.

Hipp, C. and Grupp, H. (2005) 'Innovation in the service sector: The demand for servicespecific innovation measurement concepts and typologies', Research Policy, Vol. 34, No. 4, pp.517-535.

Hoeber, L. and Hoeber, O. (in press) 'Determinants of an Innovation Process: A Case Study of Technological Innovation in a Community Sport Organization', Journal of Sport Management.

Hull, C. E. and Lio, B. H. (2006) 'Innovation in non-profit and for-profit organizations: Visionary, strategic, and financial considerations', Journal of Change Management, Vol. 6, No. 1, pp.53-65.

Jaskyte, K. and Dressler, W. W. (2005) 'Organizational culture and innovation in nonprofit human service organizations', Administration in Social Work, Vol. 29, No. 2, pp.23-41.

Lee, R.P., Ginn, G. O. and Naylor, G. (2009) 'The impact of network and environmental factors on service innovativeness', Journal of Services Marketing, Vol. 23, No. 6, pp.397-406.

Lovelock, C. and Gummesson, E. (2004) 'Whither Services Marketing? : In Search of a New Paradigm and Fresh Perspectives', Journal of Service Research, Vol. 7, No. 20, pp.2041. 
Madella, A., Bayle, E. and Tome, J. (2005) 'The organizational performance of national swimming federations in Mediterranean countries: A comparative approach', European Journal of Sport Science, Vol. 5, No. 4, pp.207-220.

Miles, I. (2005) 'Innovation in services', in Fagerberg, J., Mowery, D.C. and Nelson, R.R. (Eds.) The Oxford handbook of innovation, Oxford University Press, Oxford, UK, pp.433-458.

Mohr, L. B. (1969) 'Determinants of innovation in organizations', The American Political Science Review, Vol. 63, No. 1, pp.111-126.

Mueller, D. J. (1986) Measuring social attitudes: A handbook for researchers and practitioners, Teacher's College Press, Columbia University, New York.

Nadler, D.A. and Tushman, M.L. (1997) 'Implementing new designs: Managing organizational change', in Tushman, M.L. and Anderson, P. (Eds.), Managing strategic innovation and change, Oxford University Press, New York, pp. 595-606.

Newell, S. and Swan, J. (1995) 'The diffusion of innovations in sport organizations: An evaluative framework', Journal of Sport Management, Vol. 9, No. 3, pp.317-333.

Nunnally, J. C. (1970) Introduction to psychological measurement, McGraw-Hill, Inc., New York.

Scheerder, J., Zintz, T. and Delheye, P. (2011) 'The organisation of sports in Belgium. Between public, economic and social profit', in Sobry, C. (Ed.), Sports governance in the world: a socio-historic approach. The organization of sport in Europe: a patchwork of institutions, with few shared points, Le Manuscrit, Paris, pp. 84-113.

Subramanian, A. and Nilakanta, S. (1996) 'Organizational innovativeness: Exploring the relationship between organizational determinants of innovation, types of innovations, and measures of organizational performance', Omega, Vol. 24, No. 6, pp.631-647. 
Taylor, P. (2004) 'Driving up sport participation: Sport and volunteering' in Sport England (Ed.), Driving up participation: The challenge for sport, Sport England, London, pp.103-110.

Thibault, L., Slack, T. and Hinings, B. (1993) 'A framework for the analysis of strategy in nonprofit sport organizations', Journal of Sport Management, Vol. 7, No. 1, pp.25-43.

Toivonen, M. and Tuominen, T. (2006) 'Emergence of innovations in services: theoretical discussion and two case studies', Paper presented at the International ProACT Conference, Tampere, Finland.

Vos, S., Breesch, D, Késenne, S., Lagae, W., Van Hoecke, J., Vanreusel, B. and Scheerder, J. (2012). 'The value of human resources in non-public sports providers. The importance of volunteers in non-profit sports clubs versus professionals in for-profit fitness and health clubs', International Journal of Sport Management and Marketing, Vol. 11, $\mathrm{N}^{\circ} 1 / 2$, pp. 3-25.

Walker, R.M. (2008) 'An empirical evaluation of innovation types and organizational and environmental characteristics: Towards a configuration approach', Journal of Public Administration Research and Theory, Vol. 18, No. 4, pp.591-615.

Winand, M., Scheerder, J., Vos, S. \& Zintz, T. (2011). Attitude, changement et innovation. Les fédérations sportives communautaires de Belgique (Gestion \& Management du Sport 11) [Attitude, change and innovation. Sports federations in Belgium]. Leuven/Louvain-la-Neuve: K.U.Leuven/ Afdeling Sociale Kinesiologie \& Sportmanagement Research Unit of Social Kinesiology \& Sport Management et Université catholique de Louvain/ Chaire Olympique Henri de Baillet Latour et Jacques Rogge en Management des Organisations Sportives. 
Winand, M., Zintz, T., Bayle, E. and Robinson, L. (2010) 'Organizational performance of Olympic sport governing bodies: dealing with measurement and priorities', Managing Leisure, Vol. 15, No. 4, pp.279-307.

Wolfe, R. A. (1994) ‘Organizational innovation: Review, critique and suggested research directions', Journal of Management Studies, Vol. 31, No. 3, pp.405-431.

Wolfe, R. A., Wright, P. M. and Smart, D. L. (2006) 'Radical HRM innovation and competitive advantage: The Moneyball story', Human Resource Management, Vol. 45, No. 1, pp.111-126.

Zaltman, G., Duncan, R. and Holbek, J. (1973) Innovations and organizations, Wiley, New York.

Zintz, T. and Camy, J. (2005) Manager le changement dans les fédérations sportives en Europe [Managing change in sports federations in Europe], De Boeck Université, Brussels. 
Table 1: Operationalisation of the three-level determinants of innovation in sports federations

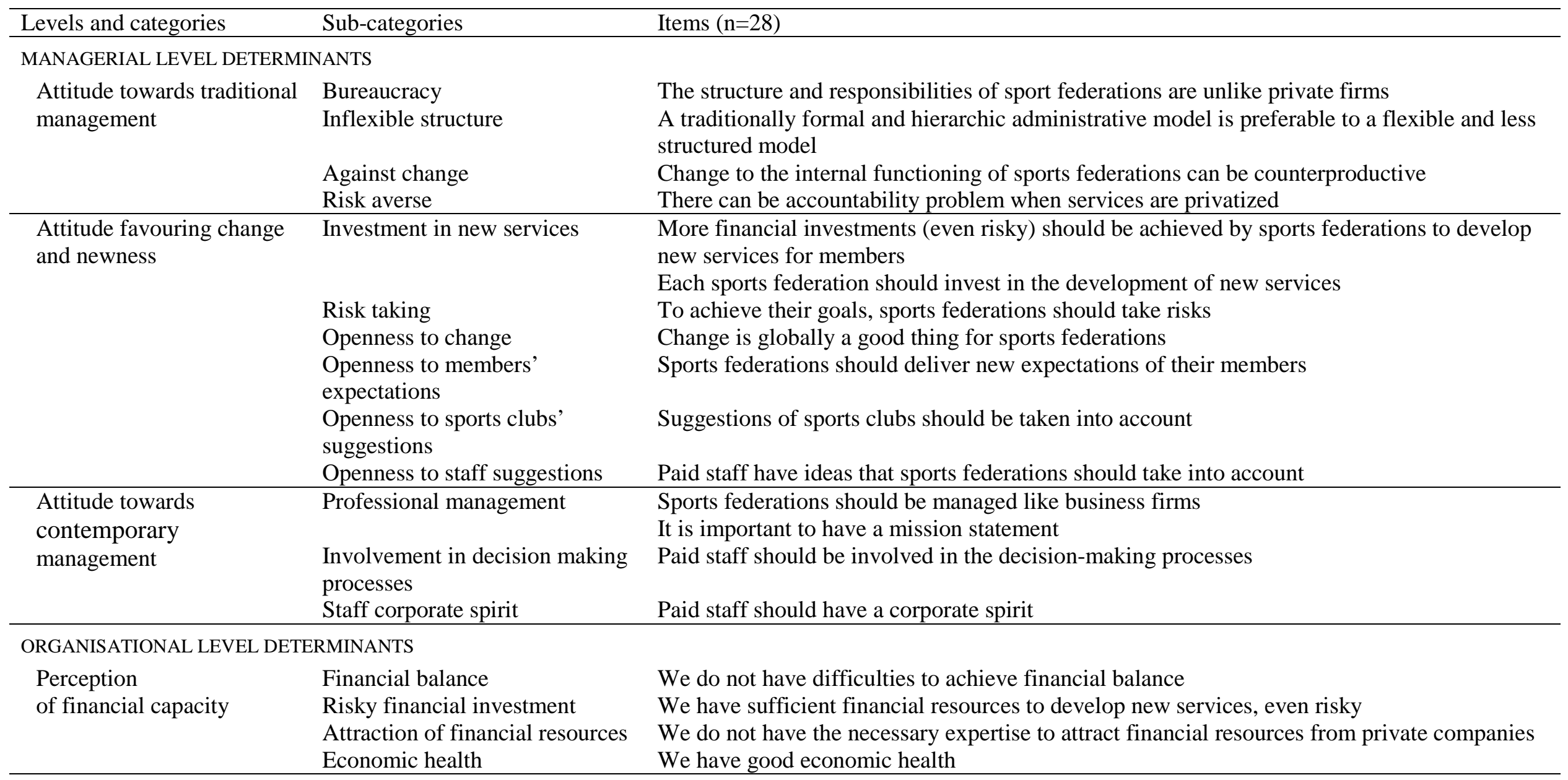


Table 1(continued)

\begin{tabular}{|c|c|c|}
\hline Levels and categories & Sub-categories & Items $(n=28)$ \\
\hline \multicolumn{3}{|c|}{ ENVIRONMENTAL LEVEL DETERMINANTS } \\
\hline \multirow{5}{*}{$\begin{array}{l}\text { Perception of competitive } \\
\text { regional environment }\end{array}$} & Attraction of members & Sports federations are competing to attract members \\
\hline & & Promoting campaigns are useful to attract future members \\
\hline & Attraction of grants & Sports federations are competing to obtain grants \\
\hline & & Competition to obtain grants is high \\
\hline & $\begin{array}{l}\text { Competition with commercial } \\
\text { sports providers }\end{array}$ & Commercial sports providers are a threat to sports federations' growth \\
\hline \multirow[t]{2}{*}{$\begin{array}{l}\text { Perception of competitive } \\
\text { national environment }\end{array}$} & $\begin{array}{l}\text { Sport rivalry between regional } \\
\text { sports federations }\end{array}$ & There is a national sport competition between regional sports federations \\
\hline & & There is a national sport rivalry between regional sports federations of the same sport \\
\hline \multirow{2}{*}{$\begin{array}{l}\text { Perception of competitive } \\
\text { international environment }\end{array}$} & High level sport competition & International sport competition between foreign sports federations is increasing \\
\hline & & Competition between foreign sports federations to obtain international sports results is high \\
\hline
\end{tabular}


Table 2: Factor analysis of the determinants of innovation for sports federations

\begin{tabular}{|c|c|c|c|c|}
\hline & Loadings & Eigenvalues & $\begin{array}{c}\% \text { of } \\
\text { variance }\end{array}$ & $\begin{array}{c}\text { Reliability } \\
\text { alpha }\end{array}$ \\
\hline \multicolumn{5}{|l|}{ FACTOR 1: ATTITUDE REGARDING STAFF INVOLVEMENT } \\
\hline Paid staff have ideas that sports federations should take into account & .862 & 3.50 & 14.36 & .73 \\
\hline Paid staff should have a corporate spirit & .749 & & & \\
\hline \multicolumn{5}{|l|}{ FACTOR 2: ATTITUDE REGARDING NEWNESS } \\
\hline Suggestions of sports clubs should be taken into account & .810 & 2.68 & 13.34 & .73 \\
\hline Sports federations should deliver new expectations of their members & .767 & & & \\
\hline $\begin{array}{l}\text { More financial investments (even risky) should be achieved by sports federations to } \\
\text { develop new services for members }\end{array}$ & .729 & & & \\
\hline Each sports federation should invest in the development of new services & .586 & & & \\
\hline \multicolumn{5}{|l|}{ FACTOR 3: PERCEPTION OF (INTER)NATIONAL COMPETITIVE ENVIRONMENT } \\
\hline International sport competition between foreign sports federations is increasing & .776 & 2.17 & 13.27 & .73 \\
\hline Competition between foreign sports federations to obtain international sports results is high & .771 & & & \\
\hline There is a national sport competition between regional sports federations & .714 & & & \\
\hline There is a national sport rivalry between regional sports federations of the same sport & .686 & & & \\
\hline We do not have difficulties to achieve financial balance & .810 & 1.65 & 12.95 & .75 \\
\hline We have sufficient financial resources to develop new services, even risky & .799 & & & \\
\hline We have good economic health & .788 & & & \\
\hline \multicolumn{5}{|l|}{ FACTOR 5: PERCEPTION OF REGIONAL COMPETITIVE ENVIRONMENT } \\
\hline Sports federations are competing to obtain grants & .923 & 1.35 & 12.82 & .72 \\
\hline Competition to obtain grants is high & .882 & & & \\
\hline Sports federations are competing to attract members & .547 & & & \\
\hline
\end{tabular}

Note. Extraction Method: Principal Component Analysis. Rotation Method: Varimax with Kaiser Normalization. Rotation converged in 6 iterations

$66.7 \%$ of variance explained by the five factors. Reliability: Cronbach's alpha

Seventeen of the 28 items showed significance (>.4) 
Table 3: Final cluster centres of the clustering method (K-means) for sports federations

\begin{tabular}{|c|c|c|c|c|}
\hline & Cluster 1 & Cluster 2 & Cluster 3 & Total mean \pm SD \\
\hline F1: Attitude regarding staff involvement & 3.71 & 4.05 & 4.37 & $4.08 \pm 0.76$ \\
\hline F2: Attitude regarding newness & 3.66 & 3.88 & 3.84 & $3.81 \pm 0.60$ \\
\hline F3: Perception of (inter)national competitive env. & 2.24 & 3.68 & 2.66 & $3.00 \pm 0.89$ \\
\hline F4: Perception of economic health & 2.70 & 3.42 & 2.45 & $2.93 \pm 0.84$ \\
\hline F5: Perception of regional competitive environment & 2.51 & 3.69 & 4.08 & $3.54 \pm 0.89$ \\
\hline Percentage of sports federations in each cluster & $23 \%$ & $44 \%$ & $33 \%$ & \\
\hline
\end{tabular}

Note. One sports federation could not be included in the clustering $(\mathrm{n}=100)$. SD: Standard deviation

Name of clusters. Cluster 1: Traditional sports federations; Cluster 2: Financially secure sports federations;

Cluster 3: Competitive sports federations 
Table 4: Results of the ANOVAs for general and sport service innovations of sports federations

\begin{tabular}{|c|c|c|c|c|}
\hline & \multicolumn{2}{|c|}{ General service innovations } & \multicolumn{2}{|c|}{ Sport service innovations } \\
\hline & Mean & $\pm S D$ & Mean & $\pm S D$ \\
\hline Traditional sports federations (Cluster 1) & $3.43^{\mathrm{a}}$ & \pm 2.54 & $1.09^{\mathrm{a}}$ & \pm 0.85 \\
\hline Financially secure sports federations (Cluster 2) & $4.45^{\mathrm{a}}$ & \pm 3.10 & $1.34^{\mathrm{ab}}$ & \pm 1.64 \\
\hline Competitive sports federations (Cluster 3 ) & 5.55 & \pm 3.80 & $2.70^{\mathrm{b}}$ & \pm 2.31 \\
\hline Significance level & ** & & * & \\
\hline Total & 4.58 & \pm 3.30 & 1.73 & \pm 1.88 \\
\hline
\end{tabular}

Note. SD: Standard deviation

${ }^{\mathrm{a}} \&{ }^{\mathrm{b}}$ indicate the result of a Tukey's post-hoc test.

Clusters with the same letter in superscript do not significantly differ.

$* p<.05 / * * p<.01$ 